\title{
Designing Assesment Task of Student Creative Thinking Assisted by Google Form
}

\author{
Rahmat Setyawan, Tatag Yuli Eko Siswono, Wiryanto \\ Post Graduate Program of Elementary Education Department \\ State University of Surabaya \\ Surabaya, Indonesia
}

\begin{abstract}
This study aims to describe the process of developing and assessing the quality of mathematical creative thinking instruments for elementary school students assisted by Google Form. The method used is a 4-D model development research carried out through four stages, namely defining, designing, developing, and distributing. The subjects in this research were students of 6th grade Ketintang I /409 elementary school Surabaya, consisting of four classes (VI A, B, C, and D) of 115 students. Data collection is done through expert validation, teacher questionnaires, student response questionnaires, and assessment of students' creative thinking. The results of the research are the process of developing an instrument for evaluating the mathematical creative thinking of elementary school students assisted by Google Form carried out with a 4-D model consisting of 4 stages: the defining stage (initialfinal analysis, students, assignments, concepts, and formulation of learning objectives), the design stage (preparation of the evaluation grid and assessment criteria as well as the initial design of the assessment instruments), the development stage (expert validation and development trials), and the deployment stage. The quality of the product development of the development of an assessment instrument for mathematical creative thinking of elementary school students assisted by Google Form is valid with an average result of instrument format validation 85 , content validation 100 and language validation 95. Very efficient (very practical) with an average efficiency result of 3.6 of maximal 4. Effective because the product produced can measure students' creative thinking abilities. Based on the analysis of creative thinking, the results of the assessment of creative thinking carried out can be used to measure the level of students' creative thinking abilities.
\end{abstract}

Keywords:- assessment instruments for creative thinking, creative thinking ability.

\section{INTRODUCTION}

Learning mathematics in elementary schools is carried out with the aim to train students to think creatively and logically to explain and solve mathematical problems that occur in students' daily lives. One of the skills students must possess is creativity. This is because the ability of people to think creatively can be one of the advantages of a country in competing with other countries, so it is very important to train creative thinking skills to children from an early age so that they are accustomed to think creatively in solving various problems [1].

Various ways can be used to measure students' creative thinking abilities. According to Balka how to measure creative thinking skills including by giving assignments to students to make mathematical problems from the information presented [2]. According to Getzles and Jackson another way to find out students' creative thinking abilities can be done by giving open questions [3].

Based on observations and interviews at Ketintang I /409 elementary school, it shows that the use of technology is still rarely done. The teacher lacks training for students in the the ability to think creatively. The assessment used by the teacher does not invite students to practice creative thinking, but it is still in the form of problem solving that has a choice of answers without inviting students to look for various answers and various alternative solutions to a mathematical problem. Therefore, we need a creative thinking assessment instrument that can train students to develop creative thinking abilities and be able to measure students' creative mathematical thinking skills.

Google Form can be used as a medium to measure students' mathematical creative thinking skills because it has a variety of supporting features, including the availability of multiple choice answers on multiple choice questions, the choice of long answers, the choice of uploading documents, and the existence of a spreadsheet feature to facilitate assessment. From some of the findings that have been described, the focus of this research is how the process of product development and quality assessment instruments for mathematical creative thinking of elementary school students is assisted by Google Form.

Assessment is a process carried out systematically to search for information in the form of descriptions, numbers and verbal, analyze, and make interpretations of information used to make a decision. The assessment carried out requires instruments in its implementation. Arikunto states that assessment instruments can be interpreted as a tool used by someone to collect information related to student learning outcomes [4]. According to Kemdikbud an assessment of good learning outcomes must have valid and reliable evidence in terms of results. Valid here can be distinguished into valid in content, valid in construct, and valid in prediction [5]. 
Creative thinking is the result of developing oneself in the form of mental activities to produce new things. Krulik et al. defines creative thinking as original thinking that consists of various complex things in the form of formulating various ideas, generating new ideas, discovering the effectiveness of ideas that have been made in solving problems, and producing results that are appropriate [6]. According to Potur \& Barkul, in creative thinking there is a problem solving process through original cognitive activities to get an optimal result by using someone's intelligence in a way that is different from the others [7].

Assessment of creative thinking abilities is different from other assessments. Silver says that there are three key components that are valued in creativity, namely fluency, flexibility and novelty [8]. Fluency can be seen from the number of answers made by students, flexibility can be seen from the number of ways students made, and novelty seen from the answers or ways students are different from usual. Based on these three indicators, Siswono makes 5 levels of categories of creative thinking abilities. Starting from level 4 (very creative), 3 (creative), 2 (quite creative), 1 (less creative), and 0 (not creative) [9].

Google form is an application created by Google to collect information online in an easy and efficient way. According to Rahardja, Google Form has various facilities that can be used freely [10]. According to Fadjilah, the features that the Google Form has are very easy to use, free, lightweight programs, have various features (short answers, long answers (paragraphs), multiple choice, check boxes (multiple choice with more than one answer), drop down and upload files), can be shared, has a spreadsheet feature. Of the various features, there are several features that support for google form measurements, including, long answers (paragraphs), check boxes (multiple choice with more than one answer), and file uploads [11].

\section{METHOD}

Research was conducted using development research with the aim of describing the feasibility of a product being developed. Research and development methods are scientific ways to research, design, produce and test the validity of products that have been produced [12]. The model used was 4-D development research proposed by Thiagarajan, et al carried out through four stages, namely defining, designing, developing, and distributing [13]. The definition was done by the initial analysis, student analysis, concept analysis, and task analysis. The design included making lattices and criteria for the assessment of creative thinking as well as making the initial design of the creative thinking assessment instrument. Development included expert validation activities and trials of the development of assessment instruments made for students. The development phase resulted in the final form of an instrument for evaluating the mathematical creative thinking of elementary school students assisted by Google Form after a revision was made based on the input of expert validators, as well as the responses of both teachers and students. Dissemination was carried out by distributing instruments that are made.
The subjects in the study were students of 6th grasde Ketintang I /409 elementary school, consisting of four classes (VI A, B, C, and D) of 115 students. The research was conducted in odd semester 2019/2020 school year, at Ketintang I /409 elementary school, Jl. Ketintang Madya No. 146, Kecamatan Gayungan, Kota Surabaya, East Java. Data collection was done through student answer sheets, student response questionnaires, teacher questionnaires, and expert validation questionnaires. After the data was obtained, it was continued with the analysis of the quality of the assessment instruments made covering the validation of the assessment instruments (validation of format, content, and language), analysis of the practicality of the instruments and analysis of the effectiveness of the assessment instruments made.

\section{RESULT AND DISCUSSION}

\section{A. Development of an assessment instrument for mathematical creative thinking for elementary school students assisted by Google Form}

Researchers developed an instrument for evaluating the mathematical creative thinking of elementary school students assisted by Google Form by the following stages.

\section{$>$ Defining Phase}

The defining stage began with the initial analysis. Researchers found out the problems encountered in learning activities, examine the curriculum, and determine alternative problem solving and research focus, namely the creation of an assessment instrument for mathematical creative thinking assisted by Google Form. The selection of assessment instruments is in accordance with Siegel and Ranney's opinion which confirms that the development of innovation in assessment instruments is able to strengthen the relevance of science taught in schools [14]. The use of Google Form was chosen because it has various features that support the measurement of students 'creative thinking abilities including (1) the availability of checkbox choices (multiple choice with more than one correct answer) to measure students' fluency levels, (2) the existence of long answer choices to measure their level of flexibility students in solving problems and the level of novelty of the answers made by students, (3) the choice of uploading documents if students have difficulty writing long answers (uploading documents is used by students writing answers on paper, then photographing and uploading photos), (4 ) there is a spreadsheet feature to facilitate separate analysis and determine the level of creative thinking of students.

The next stage is concept analysis to identify detail and arrange concepts that will be measured by creative thinking skills instruments with the help of google form. The final stage of defining is task analysis to determine the student's main skills to be measured, namely students' creative thinking abilities. 


\section{$>$ Planning Level}

This stage has the aim of designing an instrument of assessment of creative thinking using Google Forms. Activities in this stage consist of the preparation of an appraisal grid and the initial design of the appraisal instrument. The grading instrument is based on the assessment of material that has been analyzed according to learning objectives and indicators of achievement of learning outcomes. To measure students' creative thinking abilities, the questions made are in the cognitive process dimension 4 (analyzing), 5 (evaluating), and 6 (creating) dimensions [15]. In addition, the grading instrument assessment also needs to pay attention to the distribution of the level of difficulty of the questions so that in the questions made there are $20 \%$ easy category questions, $60 \%$ medium category questions, and $20 \%$ difficult category questions.

After the Google Forms formulation of mathematical creative thinking assessment instruments is completed, the next criteria for evaluating students' creative thinking abilities is arranged. The criteria for evaluating creative thinking abilities are as follows.

\begin{tabular}{|c|c|c|}
\hline Indicator & $\begin{array}{c}\text { Assessment } \\
\end{array}$ & Score \\
\hline Settlement & $\begin{array}{c}\text { The assignment answer is correct, } \\
\text { score } \\
\text { Incorrect answer, (discontinued } \\
\text { assessment) }\end{array}$ & $\begin{array}{l}1 \\
0\end{array}$ \\
\hline $\begin{array}{l}\text { Fluency } \\
\text { (Answers } \\
\text { or various } \\
\text { methods) }\end{array}$ & $\begin{array}{l}\text { If students choose all the correct } \\
\text { answers in the choice of answers } \\
\text { provided, and students can again } \\
\text { show the correct answers in addition } \\
\text { to those contained in the answer } \\
\text { choices } \\
\text { If students choose all the correct } \\
\text { answers in the choice of answers } \\
\text { provided and no longer show the } \\
\text { correct answer other than those } \\
\text { contained in the answer choices } \\
\text { If students do not answer all the } \\
\text { answers correctly in the answer } \\
\text { choices. }\end{array}$ & 0 \\
\hline $\begin{array}{l}\text { Flexibility } \\
\text { (How to } \\
\text { solve } \\
\text { more than } \\
\text { one) }\end{array}$ & $\begin{array}{l}\text { How to solve students more than one } \\
\text { way and conceptually different } \\
\text { The way students complete it is more } \\
\text { than one way and is not conceptually } \\
\text { different } \\
\text { How to complete students is only one } \\
\text { way }\end{array}$ & 2 \\
\hline $\begin{array}{l}\text { Novelty } \\
\text { (different } \\
\text { answers } \\
\text { or ways of } \\
\text { solving) }\end{array}$ & $\begin{array}{l}\text { Students show answers that are } \\
\text { different from those in the answer } \\
\text { options and don't show patterns } \\
\text { Ways more than one way and } \\
\text { different, do not show patterned } \\
\text { The answers or methods are more } \\
\text { than one and only vary } \\
\text { Answers or ways are not more than } \\
\text { one and only vary }\end{array}$ & $\begin{array}{l}2 \\
1 \\
0\end{array}$ \\
\hline
\end{tabular}

Table 1
Assessment Criteria for Students Creative Mathematical Thinking Assisted by Google Form

Preparation of an initial design assessment instrument for creative thinking assisted by Google Form pays attention to the criteria for developing creative thinking assessment instruments according to Silver which includes 3 assessments namely fluency, flexibility and novelty [16]. Therefore the questions are made to measure students' creative thinking abilities in the form of open questions. Polya says that open questions have a variety of possible correct answers to measure students' fluency in answering problems [17]. In addition, the questions created have various possible ways that can be used to solve the problems presented. The questions made also present opportunities for students to give answers or different ways than usual.

For example in the matter of package A number which will be made as follows.

- Dino heats several types of metals with different initial temperatures on the furnace at the same time. The initial temperature and the final temperature of the metal after heating are as follows.

\begin{tabular}{|c|c|c|}
\hline Metal & Starting temperature & Final Temperature \\
\hline 1 & $-6{ }^{0} \mathrm{C}$ & $60{ }^{0} \mathrm{C}$ \\
\hline 2 & $12^{0} \mathrm{C}$ & $70^{0} \mathrm{C}$ \\
\hline 3 & $-2{ }^{0} \mathrm{C}$ & $66{ }^{0} \mathrm{C}$ \\
\hline 4 & $5{ }^{0} \mathrm{C}$ & $69{ }^{0} \mathrm{C}$ \\
\hline 5 & $-4{ }^{0} \mathrm{C}$ & $62^{0} \mathrm{C}$ \\
\hline
\end{tabular}

From the change in temperature of the metal, changes in temperature exceeding $65^{\circ} \mathrm{C}$ are

$\checkmark$ Metal 1

$\checkmark$ Metal 2

$\checkmark$ Metal 3

$\checkmark$ Metal 4

From the questions made, there are several choices of correct answers, namely the choice of answers metal 1 and metal 3. From here, it will be seen indicators of the correctness of student answers. If the student's answer is correct, it will get a value of 1 and proceed to the next question for question number 3 , but if the student's answer is wrong, it will get a value of 0 and the assessment for question number 3 is stopped. After these questions, the following questions are given to students as follows.

Show me how to solve that you do. Explain the reasons for choosing that answer! 
You may write your way on paper, then take a picture and upload it to the link below.

\section{upload document}

Have you ever learned the method or your own method? $\cdots$

In the follow-up questions, students are given the task to write down the ways they use to solve problems. If students have difficulty writing directly on the link provided, students can write the way they use it on a paper and then upload it in the space provided. This follow-up question is used to see the level of flexibility of students in solving problems and the novelty of students' ways. Flexibility is seen from the many ways used by students to solve problems, while novelty is seen from the level of novelty the way the student uses it to solve problems (is it different from the usual way or does it go beyond the level of thinking of students his age). The next question is as follows.

Re-check your answer and the method you used. You can write other answers that are different from the answer choices provided and how to search for it here! (You are allowed to make the initial temperature and final temperature data different from the data provided in the table)

You may write other answers and the way you are in paper, then take a photo then upload it to the link below.

\section{upload document}

These questions are used to measure the fluency, flexibility, and novelty that students are able to show. Fluency is seen from the existence of other relevant answers besides the choice of answers provided in the answer options. Flexibility is seen from the way students use, whether different from the way that was written in the previous answer or not. Novelty is seen from the answers of students whether different principles and correct from the answers that have been written before.

\section{$>$ Development Stage}

The product design was assessed as feasible and was validated at this stage. The expert team involved in the validation process consisted of an expert assessment of creative thinking that is consistent with the subject matter of the research. Validation of assessment instruments for creative thinking assisted by Google Form was carried out by competent experts in the field of learning assessment development. The validator will provide suggestions and improvements for the assessment instruments made on the research. Corrections to be made by the validator on the learning kit included aspects of the material, presentation, language and other things that affect the appropriateness of the assessment instrument.

After the product was validated, the next step was to test the development. Trial I was conducted to 10 students of 6th grade of Ketintang I /409 elementary school to get the initial feasibility data for the assessment instrument for creative thinking assisted by Google Form. After obtaining the preliminary data, it is needed advice and input from experts so that it can be maximally developed for 6th grade students of elementary schools. After the assessment instruments were improved from the results of the first trial input, the Trial II was continued to all sixth grade students of Ketintang I $/ 409$ elementary school. Trial II was conducted to determine the extent to which the revised instrument of creative thinking assisted by the Google Form was revised from trial I feasible and effective to be used in assessing students' creative thinking.

\section{$>$ Dissemination Stage}

An instrument of assessment of creative thinking assisted by Google Form that have been developed in accordance with the feasibility based on the results of the trial can be disseminated to 6th grade teachers in the Gayungan sub-district. Because this Google Form can be accessed using the internet, teachers can access this Google Form using a computer, laptop or smartphone. Research results can also be made into educational research journals distributed online and distributed via bit.ly so that they are easily accessed and can be used as references by other teachers.

\section{B. The Quality of Google's Mathematical Assisted Creative Thinking Assessment Instrument}

The quality of the assessment instrument of mathematical creative thinking tools assisted by Google Form is seen from the results of validation, efficiency or practicality, and the effectiveness of the products made. Validation was carried out on the format, content, language and assessment of the questions on the mathematical creative thinking assessment instrument for elementary school students assisted by Google Form. Validation includes instruments for evaluating creative thinking about Package A and Package B. The revised part is in accordance with the notes or suggestions (revisions) of the validator and is followed up based on the validator's assessment. Summary of the results of the validation of the format, content, language and assessment of the questions on the creative thinking assessment instrument that has been done by validator 1 (V1) and validator 2 (V2) in table 1 below. 
ISSN No:-2456-2165

\begin{tabular}{|c|c|c|c|c|c|c|}
\hline \multirow{2}{*}{ Num. } & \multirow{2}{*}{ Validation } & \multicolumn{2}{|c|}{ Score } & \multirow{2}{*}{ Average } & \multirow{2}{*}{ Category } & \multirow{2}{*}{$\mathrm{R}(\%)$} \\
\hline & & V1 & V2 & & & \\
\hline 1. & $\begin{array}{c}\text { Question Format } \\
\text { Package A }\end{array}$ & 3,80 & 3,00 & 3,40 & Valid & 85 \\
\hline 2. & $\begin{array}{c}\text { Question Format } \\
\text { Package B } \\
\end{array}$ & 3,50 & 3,00 & 3,25 & Valid & 81,25 \\
\hline 3. & $\begin{array}{c}\text { Fill in the Questions } \\
\text { Package A }\end{array}$ & 4,00 & 4,00 & 4,00 & Very valid & 100 \\
\hline 4. & $\begin{array}{c}\text { Fill in the Questions } \\
\text { Package B }\end{array}$ & 3,70 & 4,00 & 3,85 & Very valid & 96,25 \\
\hline 5. & $\begin{array}{c}\text { Language and } \\
\text { Assessment Package A }\end{array}$ & 3,90 & 3,70 & 3,80 & Valid & 95 \\
\hline 6. & $\begin{array}{c}\text { Language and } \\
\text { Assessment Package A }\end{array}$ & 3,70 & 3,50 & 3,60 & Valid & 90 \\
\hline
\end{tabular}

Table 3:- Recapitulation of Results of Validation of format, content, language and question assessment

Table 3 shows the two validators concluded that the format, content, language and item assessment of the creative thinking assessment instrument were valid and could (properly) be used in the development of an elementary school's mathematical creative thinking assessment instrument assisted by Google Form.

Efficiency or practicality of elementary school students' mathematical creative thinking assessment instruments assisted by Google Form, can be assessed through practicality assessment by the teacher in Table 4, and student responses in table 5 .

\begin{tabular}{|c|c|c|c|c|}
\hline \multirow{2}{*}{ Rated aspect } & \multicolumn{4}{|c|}{ Rating score } \\
\cline { 2 - 5 } & $\begin{array}{c}\text { Teacher } \\
6 \mathrm{~A}\end{array}$ & $\begin{array}{c}\text { Teacher } \\
\text { 6B }\end{array}$ & $\begin{array}{c}\text { Teacher } \\
\text { 6C }\end{array}$ & $\begin{array}{c}\text { Teacher } \\
6 \mathrm{D}\end{array}$ \\
\hline Average & 3,7 & 3,6 & 3,5 & 3,6 \\
\hline $\begin{array}{c}\text { Percentage }= \\
\text { (Total score/ } \\
\text { Maximum } \\
\text { score) } x \text { 100 }\end{array}$ & 92,5 & 90,0 & 87,5 & 90,0 \\
\hline
\end{tabular}

Table 4:- Results of Practical Assessment by Teachers

Table 4 shows that from both observations by observers shows that the assessment of creative thinking assisted by Google Form in general has been carried out very well (efficiently and practically) by the teacher especially for Mathematics subject matter in 6th grade elementary school.

\begin{tabular}{|c|c|c|c|}
\hline $\begin{array}{c}\text { Number of } \\
\text { Responses }\end{array}$ & Average & $\begin{array}{c}\text { Percentage of } \\
\text { success }\end{array}$ & Category \\
\hline 115 & 37,30 & 93,26 & Very good \\
\hline
\end{tabular}

Table 5:- Student Responses

Table 5 shows observations on student responses, it can be seen that in each aspect of the assessment included in the criteria very well with an average of $93.26 \%$ means that the practicality of assessment of creative thinking assisted by Google Form in Mathematics is very good (very practical).

The effectiveness of developing Mathematics creative thinking assessment instrument assisted by Google Form can be seen from the ability of the assessment instrument developed in assessing the level of creative thinking of students. In this study the assessment of students' creative thinking abilities was conducted twice by conducting a pretest before learning and posttest after the implementation of learning. A summary of the results of the assessment of students' creative thinking abilities in each class is described below.

\begin{tabular}{|c|c|c|c|c|c|c|c|c|c|c|c|}
\hline \multirow[t]{2}{*}{ Class } & \multirow{2}{*}{$\begin{array}{c}\text { Total } \\
\text { Std }\end{array}$} & \multicolumn{2}{|c|}{ TKBK0 Student } & \multicolumn{2}{|c|}{ TKBK1 Student } & \multicolumn{2}{|c|}{ TKBK2 Student } & \multicolumn{2}{|c|}{ TKBK3 Student } & \multicolumn{2}{|c|}{ TKBK4 Student } \\
\hline & & $\operatorname{Pr}$ & $\mathrm{Po}$ & $\operatorname{Pr}$ & Po & $\operatorname{Pr}$ & Po & $\operatorname{Pr}$ & Po & $\operatorname{Pr}$ & Po \\
\hline $6 \mathrm{~A}$ & 28 & 10 & 5 & 15 & 12 & 3 & 11 & 0 & 0 & 0 & 0 \\
\hline $6 \mathrm{~B}$ & 29 & 12 & 9 & 17 & 11 & 0 & 9 & 0 & 0 & 0 & 0 \\
\hline $6 \mathrm{C}$ & 28 & 9 & 7 & 11 & 10 & 4 & 10 & 0 & 1 & 0 & 0 \\
\hline $6 \mathrm{D}$ & 30 & 11 & 6 & 17 & 13 & 2 & 10 & 0 & 1 & 0 & 0 \\
\hline \multicolumn{12}{|c|}{$\begin{array}{c}\text { Std }=\text { student } \\
\operatorname{Pr}=\text { pretest } \\
\text { Po }=\text { posttest }\end{array}$} \\
\hline
\end{tabular}

Table 6 
The results of the pretest and posttest in table 6 show that the creative thinking assessment instruments assisted by Google Form can be used to measure students' creative thinking abilities. The assessment instruments used can measure differences in students' creative thinking abilities before learning and after learning.

\section{CONCLUSIONS}

The conclusions of this study are: (1) the process of developing an instrument for evaluating the mathematical creative thinking of elementary school students assisted by Google Form can be carried out using a 4-D model; (2) The validity of the products of assessment instruments for creative thinking assisted by Google Form is valid with an average result of instrument format validation of $85 \%$, content validation of $100 \%$ and language validation of $95 \%$. Very efficient (very practical) with an average efficiency of 3.6 out of 4; practicality (efficiency) products of assessment instruments for creative thinking assisted by Google Form and the effectiveness of the creative thinking assessment instrument products assisted by Google Form is effective; (3) Based on the analysis of creative thinking, the results of the assessment of creative thinking carried out can be used to measure the increase in students' creative thinking abilities.

\section{REFERENCES}

[1]. Mahmudi, A. "Peningkatan Kemampuan Berpikir Kritis dan Disposisi Matematis Siswa SMP dengan Menggunakan Pendekatan Problem Posing. Jurnal Didaktik Matematika, 2010, Vol. 1. No.2. pp. 1-12

[2]. Balka, D. S. "Creative ability in mathematics". The Arithmetic Teacher 21, 1974, pp. $633-636$. https://pubs.nctm.org/view/journals/at/21/7/ articlep633.xml.

[3]. Getzels, J.W. \& Jackson, P.W. "Creativity and intelligence". New York: Wiley, 1962, pp 129-135.

[4]. Arikunto, Suharsimi. "Dasar-dasar Evaluasi Pendidikan”. Jakarta: PT. Bumi Aksara, 2009, pp. 72.

[5]. Kemendikbud. (2016). "Panduan Penilaian untuk Sekolah Dasar". Jakarta: Direktorat Pembinaan Sekolah Dasar Direktorat Jenderal Pendidikan Dasar dan Menengah Kementerian Pendidikan dan Kebudayaan, 2009, pp. 8.

[6]. Krulik, Stephen. And Rudnick, Jesse A. "Innovative Tasks ToImprove Critical and Creative Thinking Skills". Reston: The National Council of teachers of Mathematics, 1999, pp. 40.

[7]. Potur, A. A. \& Barkul, Ö. "Gender and Creative Thinking in Education: A Theoretical and Experimental Overview". Journal of ITU A|Z. Vol: 6 No: 244- 257-2009-2, 2009, pp. 245. https://www.researchgate.net/

[8]. Silver, E. A. "Fostering Creativity Though Instruction Rich in mathematical Problem Solving and Problem Posing”. Journal (online), 1997, pp. 78. http://www.Fizkorlsruke.de/
[9]. Siswono, Tatag Y E. (2018). "Desain Tugas untuk Mengidentifikasi Kemampuan Berpikir Kreatif Siswa dalam Matematika”. Journal (Online). 2018, pp. 40. https://tatagyes.files.wordpress.com/2007/10/ tatag_jurnal unej.pd

[10]. Rahardja, U., Lutfiani, N., Alpansuri, M.S. "Pemanfaatan Google Formulir Sebagai Sistem Pendaftaran Anggota Pada Website Aptisi.or.id", Jurnal Ilmiah SISFOTENIKA, Volume 8, Nomor 2, 2018, pp. 128-129.

[11]. Listiorini. "Tutorial Cara Membuat Google Form untuk Berbagai Keperluan”. 2020, pp. 1. https://carisinyal.com/cara-membuat-google-form/

[12]. Sugiyono. "Metode Penelitian Kuantitatif Kualitatif dan R\&D”. Bandung: CV Alfabeta. 2012, pp. 30.

[13]. Thiagarajan, Dorothy Sivasailam, S. Semmel, and Melvyn I. Semmel. "Instructional Development for Training. Teachers of Exceptional Children". Bloomington: Indiana University. 1974, pp. 5.

[14]. Siegel, M. A., dan Ranney, M. A. "Developing the Changes in Attitude about the Relevance of Science (CARS) Questionnaire and Assessing Two High School Science Classes". Journal of Research in Science Teaching, Vol. 40. 2003, pp. 757-775. https://www.researchgate.net/ publication/227625054_

[15]. Anderson, L.W., and Krathwohl., D.R. "A Taxonomy for Learning, Teaching, and Assesing; A Revision of Bloom's Taxonomy of Education Objectives". New York: Addison Wesley Lonman Inc. 2001, pp. 101102.

[16]. Silver, E. A. "Fostering Creativity Though Instruction Rich in mathematical Problem Solving and Problem Posing”. Journal (online), 1997, pp. 78. http://www.Fizkorlsruke.de/

[17]. Polya, G. "Mathematical discovery on Understanding. Learning and Teaching Problem Solving". New York: John Willey \& Sons. 1981, pp. 115. 